\title{
Developing Cultural Context Teaching Material of Geometry with GeoGebra to Increase Students' Higher-order Thinking Skill
}

\author{
Juliana M.H.Nenohai ${ }^{1}$, Ofirenty E.Nubatonis ${ }^{2}$, Damianus D.Samo ${ }^{3 *}$ \\ ${ }^{1}$ Department of Mathematics Education, Universitas Nusa Cendana, Indonesia \\ ${ }^{2}$ Department of Mathematics Education, Universitas Nusa Cendana, Indonesia \\ ${ }^{3}$ Department of Mathematics Education, Universitas Nusa Cendana, Indonesia \\ *Corresponding author. Email: damianus.damo@staf.undana.ac.id
}

\begin{abstract}
The purpose of this research is to develop teaching material of cultural context geometry with GeoGebra which is valid, practical and effective based on the theoretical reviews and its support to enhance higher-order thinking ability. This study is a research and development (R \& D) that was developed by referring to ADDIE model. The samples are the student of Mathematics Education Department at Nusa Cendana University who consists of 40 students. The data were analyzed by descriptive statistics, n-gain, and one sample pretest-posttest test. The results showed that the teaching material was valid with the average of expert evaluations 4.55 or in the good criterion. Teaching material was practical with the average value of learning activities observation 4.3 or in the good category and the students' responses is 4.05 or in the good category, and teaching material was effective because it empirically can increase the higher-order thinking ability 0.52 or in the medium category. The teaching material of cultural context geometry with GeoGebra is a unification of local knowledge and technology integration that can be used in geometry learning in order to support students' transition from elementary mathematical thinking level to advanced mathematical thinking level.
\end{abstract}

Keywords: Cultural context, GeoGebra, Higher-order Thinking.

\section{INTRODUCTION}

Higher-order thinking is an idea presented by Bloom et.al in his taxonomy education. In their taxonomy, [1] described higher-order thinking as a level of cognitive analysis, synthesis, and evaluation. The taxonomy was revised by [2] by presenting a new higher-order thinking level namely analysing; evaluating; and creating. Analysing is associated with cognitive processes by giving attributing, organizing, integrating and validating. Evaluating includes checking, critiquing, hypothesizing, and experimenting. Creating includes generating, designing, producing, and devising [3].

According to [4] higher-order thinking is a form of thinking and learning that requires greater cognitive processing and indirectly requires different forms of learning beyond memorization, facts and, concepts. This conception confirms that facts, concepts, principles, and operations are memorized parts of mathematics that are prerequisites for students to access higher-order thinking. [5] revealed that higher-order thinking can be conceptualized as a non-algorithmic, complex mode of thinking that often generates multiple solutions. [6] revealed that HOTS is divided into three categories namely knowledge transfer, critical thinking, and problem solving. [7] defines higher-order thinking is thinking on a level that is higher than memorizing facts or telling someone something back to exactly the way it was told to you. Moreover, some experts also define higher-order thinking by showing many attributes that is, as the ability to solve problems that involve critical thinking, logical, reflective, metacognition, reasoning, and creative [8]-[12]. In general, the definition of higher-order thinking developed by the experts included in the third level in Bloom's Taxonomy of revision in the study took four abilities of higher-order thinking as an indicator of the ability: reasoning ability (fourth level), critical thinking ability (fifth level) and creative thinking ability (sixth level). 
Higher-order thinking is a thinking skill. These skills are important related to developing students' capacity to be able to analyze and evaluate situations and build adaptive atti-tudes towards life situations that tend to change. According to [13] the advantage of high-level thinking is students can process text at deep levels, make judgments, and detect shades of meaning. They can make critical interpretations and demonstrate high levels of insight and sophistication in their thinking. They are able to make inferences, draw relevant and insightful conclusions, use their knowledge in new situations, and relate their thinking to other situations and to their own background knowledge. These students fare well on standardized tests and are considered to be advanced. They will indeed be prepared to function as outstanding workers and contributors in a fast-paced workplace where the emphasis is on using information rather than just knowing facts.

Referring to the results of several international surveys, Indonesian students in problem-solving activities, especially mathematics, is very low. In the higher education level, especially in mathematics education department of Nusa Cendana University, students' higher-order thinking abilities in geometry have the same conditions. This condition is caused by several factors; first, geometry lesson does not emphasize the development of higher-order thinking ability. [14] reveals every course should incorporate activities that will help all students' progress in developing analytical, critical reasoning, problemsolving, and communication skills and acquiring mathematical habits of mind. More specifically, these activities should be designed to develop and measure the progress of students in learning. Second, textbooks cannot accommodate the development of higher-order thinking ability. The analysis of some geometry textbooks that were used in learning is more emphasis on the applying level. Third, there was not integrating information and communications technology (ICT) as a learning tool that can help students understand the material and support problem-solving ability.

Development of higher-order thinking mathematics abilities can be done with the reform of learning activities in the classroom with teaching materials that accommodate the needs of developing higher-order thinking. Some of the learning models can be a solution that is contextual learning, problem-based learning, and higher-order thinking strategies. The contextual teaching and learning present the lessons to integrate everyday life issues in classroom activities. This integration can be done by integrating local culture that rarely has been the subject of classroom learning. The purpose of this integration is that students would be able to get to know their culture, learn mathematics in their culture, honor their culture, and in order to preserve their culture. In addition to the integration of local culture, the utilization of information and communication technologies are also carried out to address the problem of learning that found in geometry. Utilization of information and communication technology is performed with the use of GeoGebra. GeoGebra is dynamic mathematics software that contains geometry, algebra, and calculus. GeoGebra presents a visual display of the complete geometry that allows the user to transform the algebra into geometry and vice versa.

In this teaching material, GeoGebra has a role that is pre-senting meaningful learning. Learning by integrating GeoGebra allows students to visualize the abstract concepts in geometry in order to make students more easily understand the learning. GeoGebra presents a visual appearance in geometry with algebra that helps students examine the problem solution manually and with GeoGebra. Using GeoGebra in teaching and learning will help the students to understand the difficult tasks easily and in pursuance GeoGebra will engage students in the learning process [15] GeoGebra in particular will in great measure improve the students' learning outcomes in Mathematics, especially on students' performance in both internal and external examinations; and at the same time, their attitude towards Mathematics will be greatly enhanced [16].

Based on the description above, this study attempts to develop teaching material of cultural context geometry with GeoGebra which is valid, practical and effective based on the theoretical reviews and its support to enhance higher-order thinking ability. Validity aspects include the expert judgments of the content, language and the relation between cultural aspects and geometry content. Practical aspects include the assessment of experts that stated that the teaching material can be applied and the empirical fact that its implementation is in a good category. Effective aspects include the implementation supported the enhancement of higher-order thinking ability.

\section{METHOD}

This study is a research and development ( R \& D) that was developed by referring to ADDIE model [17]. This ADDIE provides a framework to ensure that the teaching material developed is valid, practical, and effective.

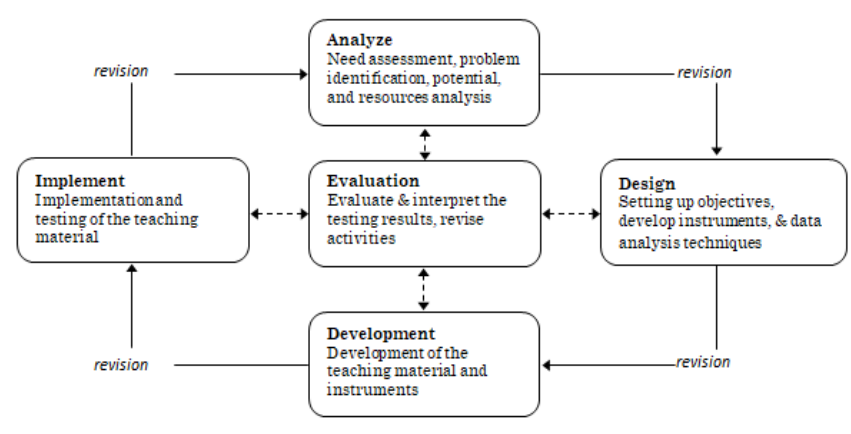


Figure 1. ADDIE framework of teaching material development

The participants are from the Mathematics Education Department Students at Nusa Cendana University who consists of 40 students. The instruments used in this study are (1) validation guidelines, (2) observation sheets of learning activities, (3) students' response questionnaire, and (4) higher-order thinking ability tests. The data were analyzed by descriptive statistics, n-gain, and one sample pretest-posttest test. The descriptions of three mathematical abilities are presented in the table below [3]

Table 1. The description of higher-order thinking ability aspects

Type of problem with higher-order thinking are made with analysis, evaluation and creative which described as the problem type of mathematical reasoning, critical, and creative thinking mathematical.

\begin{tabular}{|c|c|}
\hline Ability & Description \\
\hline $\begin{array}{l}\text { Reasoning } \\
\text { ability }\end{array}$ & $\begin{array}{l}\text { Mathematical reasoning ability is defined } \\
\text { as an argumentative thinking activity to } \\
\text { determine a conclusion. Students are said } \\
\text { having a good reasoning ability if they are } \\
\text { able to present a true problem solving, } \\
\text { provide conclusions or evidence that with a } \\
\text { logical process, accountable, follow the } \\
\text { rules or be argumentative. }\end{array}$ \\
\hline $\begin{array}{l}\text { Critical } \\
\text { thinking } \\
\text { ability }\end{array}$ & $\begin{array}{l}\text { Critical thinking ability is defined as an } \\
\text { evaluative thinking activity to determine } \\
\text { the quality of a decision based on an in- } \\
\text { depth analysis. Students are said having a } \\
\text { good critical thinking if they are able to } \\
\text { find mistakes or errors in the problem, } \\
\text { evaluate the problem, draw a conclusion } \\
\text { and make the best decision. }\end{array}$ \\
\hline $\begin{array}{l}\text { Creative } \\
\text { thinking } \\
\text { ability }\end{array}$ & $\begin{array}{l}\text { Creative thinking ability is defined as the } \\
\text { ability of problem-solving involves } \\
\text { cognitive functions in planning, } \\
\text { implementing and producing the correct } \\
\text { problem-solving in different ways and } \\
\text { creates something new. }\end{array}$ \\
\hline
\end{tabular}

\section{RESULT}

Developing teaching material of cultural context geometry begin with an exploration of East Nusa Tenggara culture, identify aspects of mathematics in the culture, integrating into learning activities as an introduction and evaluation also the use of technologyassisted with the program GeoGebra. The conceptual design exploration, identification, integration of culture and technology and the evaluation is presented as follows.

Table 2 Material and some culture descriptions.

Material Culture and its description

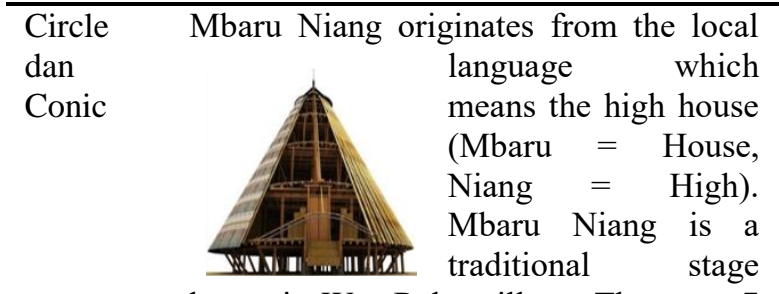

house in Wae Rebo village. There are 7 Mbaru Niang which means with respect to the 7 directions of the wind from the tops of the mountains that surround the village Wae Rebo. Mbaru Niang has a conic shape with $15 \mathrm{~m}$ height. The roof is

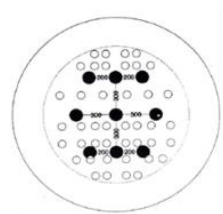
made of palm with roof framework of bamboo and the main pillars that uses the big worok wood taken from the full timber tree. Mbaru Niang has 5 floors with the diameter of $11 \mathrm{~m}, 9 \mathrm{~m}, 6 \mathrm{~m}, 3 \mathrm{~m}$ and $1,8 \mathrm{~m}$ for each floor are. Mbaru Niang floor section which is a structural pillar can be presented in figure 2 . The black nodes have 9 pieces showed the main pillars of Mbaru Niang arranged with a neat pattern with the right size. The people of Wae Rebo, can show a geometry shape of the circle and cone perfectly agree with mathematical concept if applied formally. A thorough study will show how the people work until the geometry shapes of a circle and cone are formed in accordance with the properties of the cone and circle that are learned in the classroom. Another mathematics aspect that was found is the number of wood as a crutch Mbaru Niang. The amount of stanchion that was used on each floor seemed to be a pattern from the first floor until the fifth floor and the measurement for each wood that is used formed a symmetry structures

Circle Wologai traditional village is located in

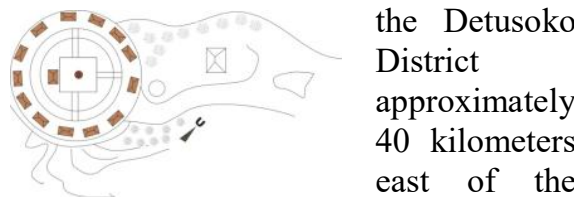

town of Ende. Settlement pattern of Wologai traditional village formed a cluster. Sa'o, the traditional house, was built to surround Keda and Kanga. Keda and Kanga are the sanctity symbol of Wologai traditional village. Keda is a traditional house that is sacred to the Ende-Lio people with a purpose of storing the sacred object. Kanga is a pillar which acts as the place for gift that 


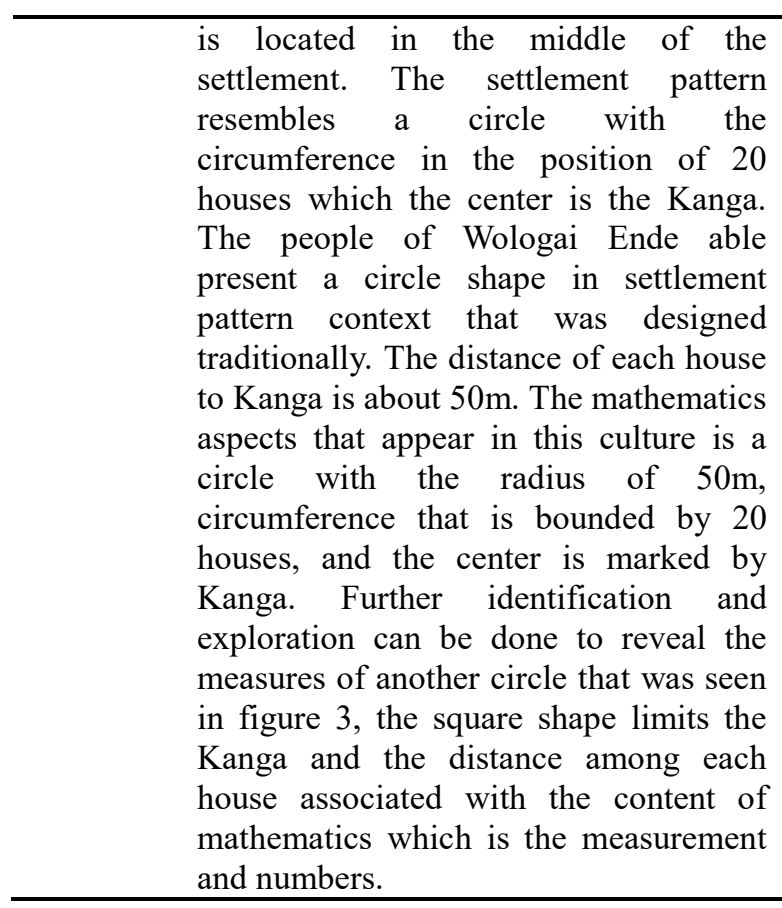

The conceptual design of teaching material developing is presented as follows:

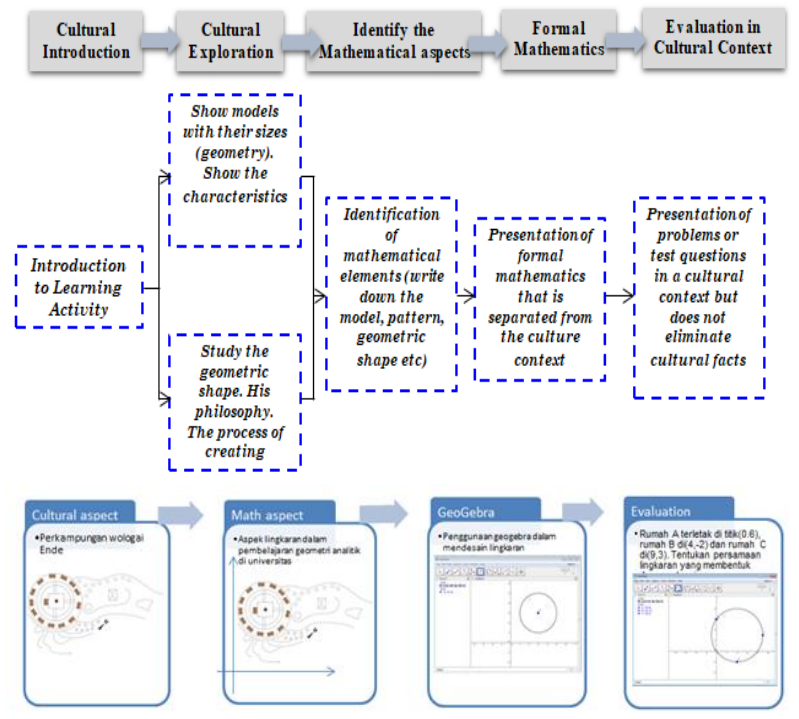

Figure 2. The conceptual design of teaching material developing

The teaching material design was validated by three experts who have competencies in mathematics and geometry. The validity of teaching material by experts is shown in the table below

Table 3. Validity of teaching material evaluated by experts.

\begin{tabular}{|c|c|c|c|c|c|}
\hline \multirow{2}{*}{$\begin{array}{c}\text { Detail of } \\
\text { evaluation }\end{array}$} & \multicolumn{4}{|c|}{ Result of evaluation } & \multirow[b]{2}{*}{ Validity } \\
\hline & $\begin{array}{c}\text { Expert } \\
1\end{array}$ & $\begin{array}{c}\text { Expert } \\
2\end{array}$ & $\begin{array}{c}\text { Expert } \\
3\end{array}$ & Average & \\
\hline Content & 4 & 5 & 5 & 4.67 & Valid \\
\hline
\end{tabular}

\begin{tabular}{cccccc}
\hline Language & 4 & 4 & 4 & 4 & Valid \\
Cultural & 5 & 5 & 5 & 5 & Valid \\
aspect & & & & & \\
$\begin{array}{c}\text { Average } \\
\text { Score }\end{array}$ & & & & 4.55 & Valid \\
\hline
\end{tabular}

3; fair 4; good 5; very good

Validity aspects include the expert judgments of content, language and the relation between cultural aspects and geometry content. The assessment of learning content resulted in the average value 4,67 or in the valid category. The content is in accordance with the basic competency and learning indicators of geometry. The content of the teaching materials contain the description of the material completely and structured i.e. introduction to the culture, the introduction of the material, the core material, sample questions, practice and integration of GeoGebra. The language assessment resulted in the average value 4.00 or in the valid category. The culture aspect assessment resulted in the average value 5.00 or in the valid category. This assessment includes the suitability of the cultural aspects that are displayed with the material being taught.

The achievement and the n-gain average of higherorder thinking ability can be presented in Table 4.

Table 4. Data description of the students' higher-order thinking ability

\begin{tabular}{llllll}
\hline Abilities & Test & $\begin{array}{c}\text { Averag } \\
\mathrm{e}\end{array}$ & $\begin{array}{c}\text { SD } \\
\text { gai } \\
\mathrm{n}\end{array}$ & $\begin{array}{c}\text { Categor } \\
\mathrm{y}\end{array}$ \\
\hline $\begin{array}{l}\text { Reasonin } \\
\mathrm{g}\end{array}$ & $\begin{array}{l}\text { Pre } \\
\text { Pos }\end{array}$ & 4.667 & 6.102 & .58 & Medium \\
& $\mathrm{t}$ & 60.088 & 20.784 & 1 & \\
Critical & Pre & .666 & 3.6514 & .55 & \\
thinking & Pos & 55.666 & 21.202 & 6 & Medium \\
Creative & Pre & .000 & .000 & .46 & \\
thinking & Pos & 46.50 & 24.429 & 5 & Medium \\
Higher- & Pre & 1.850 & 2.2660 & .52 & \\
order & Pos & 52.716 & 15.252 & 0 & Medium \\
thinking & $\mathrm{t}$ & & 4 & & \\
\hline
\end{tabular}

Based on the table, geometry learning using culturebased teaching materials with GeoGebra can improve higher-order thinking with the average value of $n$-gain 0.5200 or in the medium category. The biggest improvement is the reasoning ability 0.5813 . Increased the reasoning ability is greater than the other mathematical ability that is caused the reasoning problems are the general problem that emphasizes the use of mathematical calculations and the use GeoGebra procedurally which describe the right solution helpful. Meanwhile, two other abilities are not dependent on GeoGebra entirely because critical and creative thinking 
requires more than just calculate mathematically. Data on Table 3 can be presented in figure 3
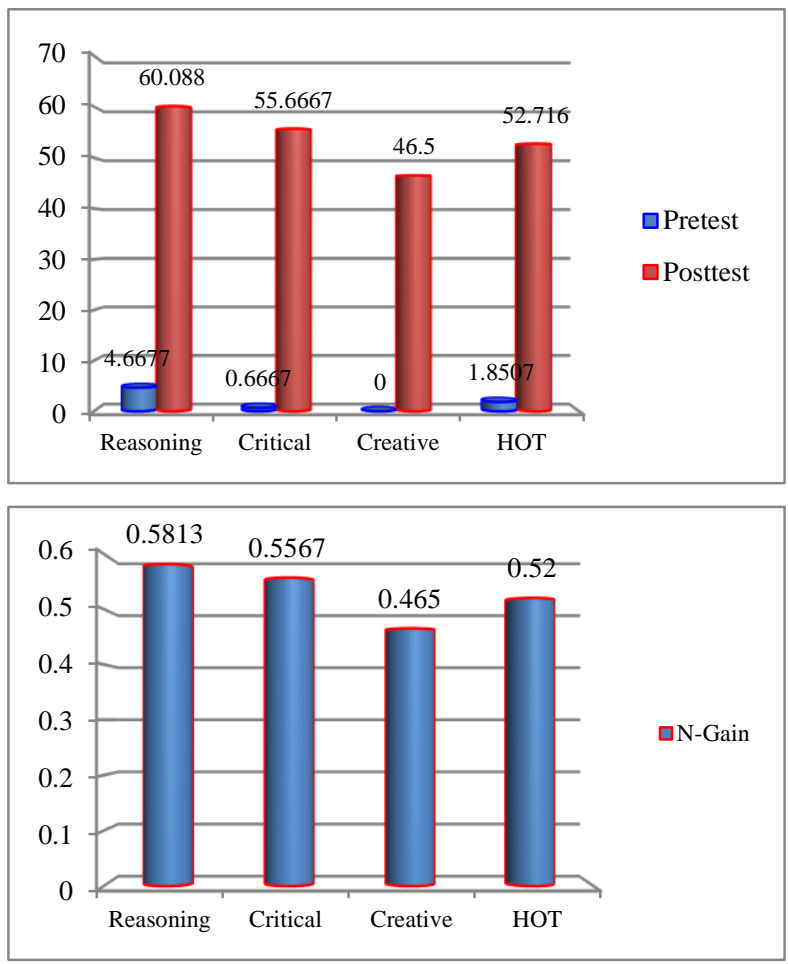

Figure 3 Students' achievement and enhancement of higher-order thinking ability

Normality test results and the comparison of pretest and posttest of higher-order thinking ability score are presented in Table 5

Table 5. Achievement comparison of higher-order thinking ability

\begin{tabular}{|c|c|c|c|c|c|c|c|}
\hline \multirow[b]{2}{*}{ Groups } & \multirow[b]{2}{*}{ Test } & \multicolumn{3}{|c|}{ Normality } & \multicolumn{3}{|c|}{ Statistic test } \\
\hline & & $\mathrm{KS}$ & df & Sig. & Stat & $\mathrm{df}$ & $\mathrm{Sig}$ \\
\hline \multirow{2}{*}{$\begin{array}{c}\text { Reasoni } \\
\text { ng }\end{array}$} & Pre & .278 & 40 & .000 & \multirow[b]{2}{*}{$Z=-4.78$} & \multirow[b]{2}{*}{39} & \multirow[b]{2}{*}{.00} \\
\hline & Post & .138 & 40 & . 150 & & & \\
\hline \multirow[b]{2}{*}{ Critical } & Pre & .539 & 40 & .000 & \multirow[b]{2}{*}{$Z=-4.79$} & \multirow[b]{2}{*}{39} & \multirow[b]{2}{*}{.00} \\
\hline & Post & .137 & 40 & .159 & & & \\
\hline \multirow{2}{*}{$\begin{array}{c}\text { Creativ } \\
\mathrm{e}\end{array}$} & & .200 & 40 & .000 & \multirow{2}{*}{$\mathrm{t}=-10.42$} & \multirow{2}{*}{39} & \multirow{2}{*}{.00} \\
\hline & Post & .272 & 40 & .000 & & & \\
\hline \multirow{2}{*}{ HOTS } & Pre & .26 & 40 & .000 & \multirow{2}{*}{$Z=-4.78$} & \multirow{2}{*}{39} & \multirow{2}{*}{.00} \\
\hline & Post & .173 & 40 & .155 & & & \\
\hline
\end{tabular}

The table above shows the probability value (sig.) of normality data test is greater than 0.05 in posttest score of reasoning ability, posttest critical thinking ability, and posttest higher-order thinking so that the achievement originated from the populations that are not normally distributed. Because the data are not normally distributed then the statistic used a different test of enhancing the pretest and posttest average by Wilcoxon test. The probability value (sig.) of normality data test of creative thinking ability is less than 0.05 so that the achievement data came from normally distributed populations. Because the data are normally distributed then statistic test for enhancing creative ability use statistic t-test. The test results, the probability value (Sig.) is less than 0.05 , so it can be concluded that an enhancing higher-order thinking ability significantly.

The observation of learning activities related to the use of teaching material in the order right. The learning activities are observed by two observers. Every observer provided an evaluation of the evaluation sheet provided. The results of observations can be shown in table 6 .

Table 6. The observation results of learning activities.

\begin{tabular}{|c|c|c|c|c|}
\hline \multirow{2}{*}{$\begin{array}{l}\text { Item } \\
\text { observation }\end{array}$} & \multicolumn{2}{|c|}{ Value } & \multirow[b]{2}{*}{ Average } & \multirow[b]{2}{*}{ Category } \\
\hline & $\begin{array}{c}\text { Observer } \\
1\end{array}$ & $\begin{array}{c}\text { Observer } \\
2\end{array}$ & & \\
\hline $\begin{array}{l}\text { Learning } \\
\text { introduction } \\
\text { presentation }\end{array}$ & 4 & 4 & 4 & Good \\
\hline $\begin{array}{l}\text { Exploration } \\
\text { mathematics } \\
\text { aspects in } \\
\text { local culture }\end{array}$ & 4 & 5 & 4.5 & Good \\
\hline $\begin{array}{l}\text { Present the } \\
\text { mathematics } \\
\text { content }\end{array}$ & 4 & 4 & 4 & Good \\
\hline $\begin{array}{l}\text { Utilization } \\
\text { GeoGebra }\end{array}$ & 5 & 5 & 5 & Good \\
\hline $\begin{array}{l}\text { HOT } \\
\text { evaluation } \\
\text { type }\end{array}$ & 4 & 4 & 4 & Good \\
\hline Average & & & 4.3 & Good \\
\hline
\end{tabular}

The observation of learning activities was seen on the five elements of the learning activities. The five elements were observed by the observer and have an average in the good category. Learning introduction presentation has an average 4.0, exploration mathematics aspects in local culture has an average 4.5, present the mathematics content has an average 4.0, utilization GeoGebra has an average 5.0, higher-order thinking evaluation type has an average 4.0. The results of observations in table 4 can be shown in figure 4 . 


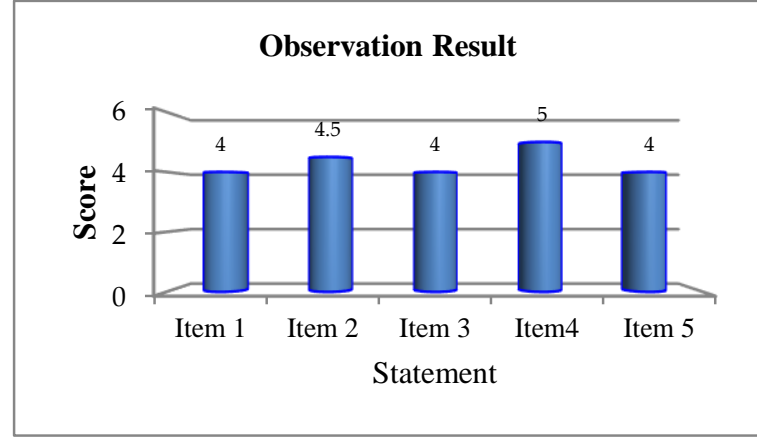

Figure 4. The observation results of learning activities

The analysis results of students' response can be presented in Table 7

Table 7. The questionnaire results of students' response.

\begin{tabular}{lcc}
\hline \multicolumn{1}{c}{ Item observation } & Average & Category \\
\hline $\begin{array}{l}\text { Content of teaching material in } \\
\text { cultural context with GeoGebra }\end{array}$ & 4.03 & Good \\
$\begin{array}{l}\text { The novelty of teaching } \\
\text { material in cultural context with }\end{array}$ & 4.33 & Good \\
GeoGebra & & \\
$\begin{array}{l}\text { Readiness for further geometry } \\
\text { learning with teaching material } \\
\text { in cultural context with }\end{array}$ & 4.16 & Good \\
$\begin{array}{l}\text { GeoGebra } \\
\text { The use of the Indonesian }\end{array}$ & 4.26 & Good \\
language in teaching material \\
$\begin{array}{l}\text { Display images in teaching } \\
\text { material }\end{array}$ & 3.63 & Good \\
$\begin{array}{l}\text { Higher-order } \\
\text { evaluation type thinking }\end{array}$ & 3.93 & \\
Average & 4.05 & Good \\
\hline
\end{tabular}

The result of the students' responses is 4.05 , so it can be concluded that the students' responses in learning are in the good category. The students' responses on table 6 can be shown in figure 5 .

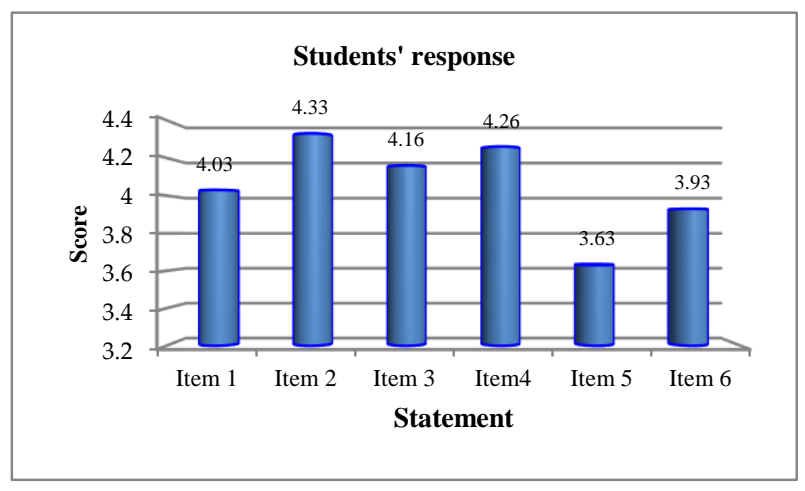

Figure 5. The questionnaire results of students' responses

\section{DISSCUSSION}

Teaching materials meet all the three criteria based on the assessment of experts, the implementation, and the learning outcomes. These teaching material have the advantages of (1) to integrate the wealth of local culture that has not become part of the learning activities yet, (2) to integrate technology as a medium that supports the understanding and ability to think, 3) to present the design of contextual learning geometry, and (4) to support the improvement of the thinking ability completely that can be obtained from the sample questions and the evaluation of learning activities.

Higher-order thinking ability in this research is defined as reasoning, critical thinking, and creative thinking ability. Developing teaching material of cultural context geometry with GeoGebra can increase higher-order thinking ability. Teaching material is valid, practical and effective. Researcher develop teaching material of cultural context geometry with GeoGebra for practical reasons, (1) the context of people's life is closely related to the geometry characteristics that can be utilized in the classroom, (2) linkage geometry with the cultural characteristics allows students to learn geometry in the life context which they know, (3) the First Year university student is a transition period that must be supported by the development of directed thinking to the characteristics of deductive mathematics, (4) mathematics with cultural context can be a way of knowledge, recognition and lead to the preservation of culture, (5) the modern mathematics is experts thinking result that comes from observations of the culture and the environment, (6) in addition, integrate GeoGebra as a learning support is aimed to introduce geometry teaching media and train students to integrate technology in learning when it was to become a teacher.

Geometry is one of content mathematics subjects that are taught in university especially in mathematics education department. The experience can have a significant impact on academic success, perseverance and student retention. According to [18] the process has serious implications for individual learners; but implications extend to universities and organizations as well. Furthermore, [19] reveals four strategies to guide ongoing discussions and planning associated with enhancing the student in university, two of them are: 1) Establishing a systematic approach to monitoring and evaluating the quality, with a particular focus on analyzing and responding to demographic subgroup differences in your student population. This may take the form of surveys, focus group discussions, or one-toone interviews by email or over the phone. Aim for a range of approaches to avoid survey fatigue. Once you have collected the data, ensure that you have strategies in place to respond to it.

Consider the implications of your findings for policy and practice across the university. Importantly, the plan for ways in which you will give feedback to students on your findings and how you have responded to their input. This is critical for establishing a reciprocal relationship of trust between students and the institution; 
2) Developing strategies to support both academic and social. This will involve collaboration between academic staff and student support staff. It will also necessitate curriculum review activities to ensure that all dimensions of the curriculum, including assessment, are appropriately designed to (a) scaffold student learning with a view to developing increased independence; (b) provide early and ongoing feedback on progress through a range of formative and summative approaches; (c) introduce students to your disciplinary culture, the language, conventions, and ways of knowing and learning in the discipline. Make tacit knowledge in this regard as explicit as possible to facilitate successful academic transition; (d) support students at key milestones in the first year, particularly during stressful periods such as when assignments are due; (e) connect students with their peers to foster collaborative learning and a sense of belonging to the learning community.

The effectiveness of teaching material in developing thinking ability is caused by the real context helps students floated the idea independently and use GeoGebra as media to check the problem which has solved manually. Teaching material and culture-based learning with GeoGebra present an opportunity for students to learn mathematics with priority in thinking than calculation. The students are trained to learn to think out of a box with critical, analytical and creative questions. In addition, students are trained to solve unstructured problems. The largest of enhancing higherorder thinking ability contained in reasoning aspects. In this aspect, students solve some cultural context problems separate problem in small parts and finishing with a logical argument and accountable to the correct conclusion. Reasoning problem is more often students found in mathematics learning activities at the level of previous education. The difference between the developed learning and the traditional one is the integration of cultural context. The smallest increment of higher-order thinking is the creative thinking aspect. Creative thinking problem requires students to make something new and different from the other students. This type of problem is the type of questions students had never studied before. Students are often taught to solve problems with the same procedure. Students are more often given exercises that closed problem and convergent. These habits lead to make students do not become creative and also do not be able to bring the students to make them different in problem-solving.

In fact, many researchers showed the cultural context in learning mathematics with different formulations. [20] in his research showed Buton coastal culture, South Sulawesi Province as part of the junior high school mathematics learning to enhance the problem solving, mathematical communication and social skills. [21] showed the Maluku culture in learning activities in high school geometry transformation. It used heuristic learning strategies to improve creative thinking ability, problem solving and self-awareness. [22]presented the realistic mathematics learning of Maluku culture. These learning activities focus on plane geometry learning in junior high school with the goal of improving students' critical and creative thinking ability.

This paper has highlighted the importance of developing higher-order thinking ability for University Student. This teaching material meets the valid aspects, practical and effective. In its implementation should be taught with contextual learning that involves group discussion and active participation. The grain in this teaching material is limited and can be developed in the other cultural context according to the regional characteristics. The teaching materials are an illustration of the integration of culture and technology into learning that can be developed with other mathematical software, the other material and the level of primary and secondary education. Next researchers can integrate the other geometry learning software to enrich the knowledge of ICT integration into learning. In addition, the aspect of higher-order thinking ability can be studied and applied according to the characteristics of learning materials.

\section{CONCLUSIONS}

This paper focuses on developing higher-order thinking skills for mathematics education department students at the University of Nusa Cendana using cultural context teaching material and technology integration. This combination has the novelty of the student's cultural context as initial knowledge and technology integration as a feature of modern learning. This teaching material is developed systematically according to the stages of development, namely analyzing, design, development, implement, and evaluation. This teaching material fulfills the valid aspects according to expert judgment based on content and format aspects; practical aspects based on measuring student responses and learning observations, and the effectiveness aspect based on the increasing higher-order thinking test. The presentation in this teaching material is limited and can be developed in other cultural contexts according to regional characteristics. Teaching materials are a description of the integration of culture and technology into learning that can be developed with other mathematics software, other materials as well as primary and secondary education levels. Further researchers can integrate other geometry learning software to enrich the knowledge of ICT integration into learning. In addition, aspects of higher-order thinking skills can be studied and applied in accordance with the characteristics of the learning material.

\section{AUTHORS' CONTRIBUTIONS}

Author 1: design and implementation of the research, wrote the manuscript 
Author 2: collected the data, performed the analytic calculation, wrote the manuscript

Author 3: conceived the presented idea, design the research, wrote the manuscript

\section{ACKNOWLEDGMENTS}

I would like to thank the mathematic education students, Nusa Cendana University for their support, without their help this work would have never been possible.

\section{REFERENCES}

[1] D. R. Bloom B, Englehart M, Furst E, H. W. and Krathwohl, Taxonomy of educational objectives: The classification of educational goals Handbook I: Cognitive domain. New York: Addison Wesley Longman, Inc, 1956.

[2] L. W. Anderson and D. R. Krathwohl, A taxonomy for learning, teaching, and assessing: A revision of Bloom's taxonomy of educational objectives. New York: Addison Wesley Longman, Inc, 2001.

[3] D. D. Samo, "Higher-order Thinking Ability among University Students: how does Culturebased Contextual Learning with GeoGebra affect," Int. J. Innov. Creat. Chang., vol. 5, no. 3, pp. 94 $115,2019$.

[4] C. E. Cook and S. Decary, "Higher order thinking about differential diagnosis," Brazilian J. Phys. Ther., vol. 24, no. 1, pp. 1-7, 2020.

[5] B. Miri, B. C. David, and Z. Uri, "Purposely teaching for the promotion of higher-order thinking skills: a case of critical thinking," Springer Res Sci Educ, vol. 37, pp. 353-369, 2007.

[6] S. M. Brookhart, How to assess higher-order thinking skills in your classroom. Alexandria: ASCD, 2010.

[7] A. Thomas and G. Thorne, "Higher order thinking,"

http://www.readingrockets.org/article/higherorder-thinking, 2014 . .

[8] A. Lewis and D. Smith, "Defining higher order thinking," Theory Pract., vol. 32, no. 3, pp. 131137, 1993.

[9] J. R. Star, "Does the learning of mathematics build higher-order thinking skills? Harvard University Graduate School of Education," https://www.gse.harvard.edu/sites/default/files/fac ulty/documents/jon-star-79295.pdf, 2003. .

[10] K. Kruger, "Higher order thinking," http://hswow.s3.amazonaws.com/02-132013/higher_thinking_02-13-2013.pdf, 2013. .
[11] C. Murray, E., "Implementing higher-order thinking in middle school mathematics classrooms," University of Georgia, 2011.

[12] F. J. King, L. Goodson, and F. Rohani, "Higherorder thinking skills 2011 Center for advancement of learning and assessment," www.cala.fsu.edu, 2011.

[13] K. Tankersley, Literacy Strategies for Grades 412. Alexandria: ASCD, 2005.

[14] MAA, "Develop mathematical thinking and communications skills," http://www.maa.org/programs/faculty-anddepartments/curriculum-department-guidelinesrecommendations/cupm/illustrativeresources/develop-mathematical-thinking, 2014.

[15] V. Naganjaneyulu and R. Srinivas, "GeoGebra as a teaching and learning tool for engineering mathematics," Open J. Appl. Theor. Math. (OJATM), vol. 2, no. 4, pp. 581-686, 2016.

[16] A. Akanmu, "Effect of GeoGebra package on learning outcomes of mathematics (secondary school) students in Ogbomoso North Local Government Area of Oyo State," GeoGebra Int. J. Rom., vol. 5, no. 2, pp. 83-94, 2016.

[17] M. Branch, R., Instructional design: The ADDIE approach. New York: Springer, 2009.

[18] J. Hays and M. Clements, "Transition: Bridging the gap between study and work," http://www.waceinc.org/bahcesehir2012/cp/refere ed/ Australia/Jay\%20Hays, \%20Mike\%20Clements, \%20Swinb urne\%20University\%20of\%20Technology\%20(Res earch)\%20Transition\%20

$\% 20$ Bridging\%20the\%20Gap\%20between\%20Stu dy\%20and\%20Work.pdf., 2012.

[19] K. Krause, "Transition to and through the first year: strategies to enhance the student experience," https://www.griffith.edu.au/_data/assets/pdf_filel 0008/39275/USCKeynoteFinal2006.pdf, 2006.

[20] et al. Kadir, "Coastal context in learning mathematics to enhance mathematical problemsolving skills of secondary school students," in Proceedings of the 14th International Conference on Education and Educational Technology (Malaysia), 2015, p. 95.

[21] S. S. Tandiseru, "The effectiveness of local culture-based mathematical heuristic-kr learning towards enhancing student's creative thinking skill," J. Educ. Pract., vol. 6, no. 12, pp. 74-81, 2015.

[22] A. Palinussa, "Kemampuan berpikir kritis dan kreatif mathematics serta karakter siswa dalam pembelajaran matematika realistik berbasis budaya," Indonesia University of Education, 2012. 